\title{
Note on Definitions
}

Any reader who jumps to the middle of this book to examine a particular colony or individual should be aware that two crucial sets of terms are used throughout this work in an unusual way. Party and faction always appear in these pages in eighteenth-century dress; that is, they refer to those loose congeries of individuals who came together because of similar views on one or more issues. Only occasionally were these groups reinforced by the formal organizational structures that the twentieth century associates with "party."

Still more important for an understanding of this book are the words expansionism, expansionist, and nonexpansionist. Expansionism, as used in this work, is the heartfelt conviction that America could and should aspire to greatness. Thomas Jefferson discoursed on this world view in the first drafts of the Declaration of Independence. Referring to the ties between Britain and the United States, he observed: "We might have been a free and a great people together; but a communication of grandeur and of freedom it seems is below their dignity. Be it so, since they will have it; the road to glory and happiness is open to us too; we will climb it in a separate state, and acquiesce in the necessity which pronounces our everlasting Adieu."1 Expansionists were those upper-class individuals who held such an outlook and who were actively committed to promoting the rise of the New World. Nonexpansionists, by contrast, were the well-to-do

1. Thomas Jefferson, "Original Rough Draught" of the Declaration of Independence, June 11-July 4, 1776, The Papers of Thomas Jefferson, ed. Julian P. Boyd et al. (Princeton, 1950- ), 1, 423-28, quotation on 427. 
citizens with little faith in America's ability to assert itself in a world of hostile nations, and hence they were unwilling to support the bold steps needed to strengthen the sovereignty of the colonies. Both sets of terms are discussed at much greater length in the Introduction. 